\title{
TANITMA 2: Sarah Dillon: Palimpsest: Edebiyat, Eleştiri, Kuram. İstanbul: Koç Üniversitesi 2017, $217 \mathrm{~s}$.
}

\section{Gülizar KULAKLI'}

Cambridge Üniversitesi İngilizce bölümünde öğretim üyesi olan Sarah Dillon edebiyat başta olmak üzere eleştiri, kuram, feminist edebiyat, film eleştirmenliği ve kuramcılığı, dilbilim gibi pek çok alanda çalışmalar yapmış ve alana önemli katkıda bulunmuş bir akademisyendir. Birinci baskısı Eylül 2017'de yayımlanan Palimpsest Ferit Burak Aydar'ın çevirisiyle aynı yıl Türkçeye kazandırılmıştır.

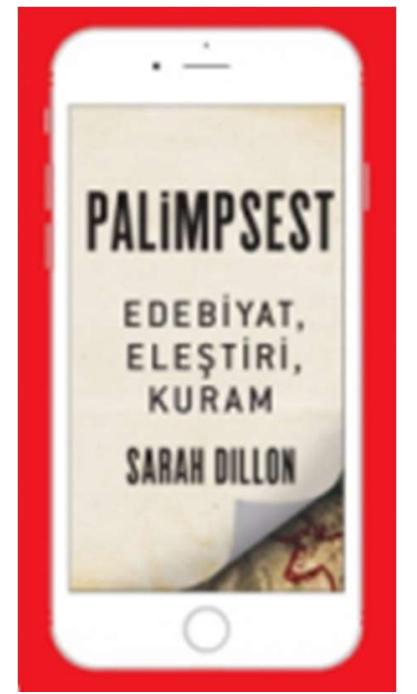

Eser yedi ana bölümden meydana gelmiştir: "Giriş: Palimpsest", "Palimpsestlerin Bir Tarihçesi”, "Zihnin Palimpsesti", "Şiir Sanatı ve Metafor Üzerine”, "Riskli Okuma”, "Metinlerarasılığı Yeniden Düşünmek", "Palimpsestin Queer'leştirilmesi: H.D.” Bu yedi ana bölümden bazıları kendi içerisinde alt başlıklara ayrılır. Dillon son olarak "Notlar", "Kaynakça” ve "Dizin" kısımlarıyla eserini tamamlar.

"Giriş: Palimpsest" başlı̆̆ını taşıyan birinci bölümde Dillon, palimpsest kelimesini ele alarak ortaya koymuş olduğu çalışmasının amaçlarını genel hatlarıyla çizmektedir:

“Bu çalışma palimpsestin 1845'ten bu yana yer aldığı yaratıcı, eleştirel ve kuramsal metinlerin birçoğunu, palimpsestin mantığını ve yapısını araştırıp modern düşünceyi anlama ve ilerletmedeki hayati rolünü göstermek amacıyla bir araya getiriyor. Tarih, öznellik, zamansallı, metafor ve cinsellik kadar farkl kavramlarm palimpsest tarafindan yeniden ölçülüp biçilmesini ele altrken, en geniş anlamıla okuma sorununa tekrar tekrar ve bıkıp usanmadan geri dönüyor. Gerek kuramda gerek eleştiride, akademik ve daha genel kültürel inançta en temel görüş ayrılıklarının kaynağı olan bir pratiği eşeliyor: Etrafımızdaki dünyayı ve kendimizi nasıl anlarız? Başka bir deyişle, nasıl okuruz? Benim açımdan bu sorunun cevabı (ister tarihsel, ister edebi, ister eleştirel, ister kuramsal, ister siyasal, ister kültürel olun) metinleri nasıl okuduğumuzun palimpsest yoluyla devamlı irdelenmesiyle bulunabilir. Dolayısıyla bu çalışma yazı ve metinselliğin doğasını tutarlhlkla araştırıyor, okumanın güvencesizliğini kabul ediyor ve riskli olmasından ötürü en verimli olan okumanın içerdiği hazdan hiç utanmadan zevk alıyor.” (Dillon 2017: 15.)

Palimpsest kelimesinin sözlükte "üstündeki elyazmasından temizlenerek tekrar tekrar kullanılmış parşömen parçası” anlamına geldiğini söyleyen Dillon’a göre, bu kelimeyi mecazi anlamda kullanan ilk yazar Thomas De Quincey değildir; fakat bu kelimenin 19. yüzyılın ortalarından günümüze kadar tutarlı bir metaforlaşma sürecine girmesinde De Quincey’in etkin bir rolü olmuştur. Bu bölümde palimpsest kelimesinin disiplinlerarası niteliği vurgulanarak birçok alanda kullanıldığına işaret edilmiştir. (Mimari, Coğrafya, Jeoloji, Paleontoloji, Sinirbilim, Genetik, Nörobiyoloji bu alanlardan bazılarıdır.). Çalışmasının "performatif" özelliğinin olmasına dikkat çeken Dillon, bu bölümde edebi metinlerinden yararlandığı Thomas De Quincey, D.H. Lawrence, Arthur Conan Doyle, Umberto Eco, Ian McEwan ve H.D. gibi yazarların isimlerini zikretmekten geri durmamıştır. Dillon palimpsest kavramının çağrıştırdığı "kıvrımlı, içe kıvrık, girift" gibi anlamların da eser içerisinde metinler üzerinden incelendiğini ve her bölümde palimpsest kelimesiyle metinlerin ilişkisini sorgulayarak bu girift yapıyı

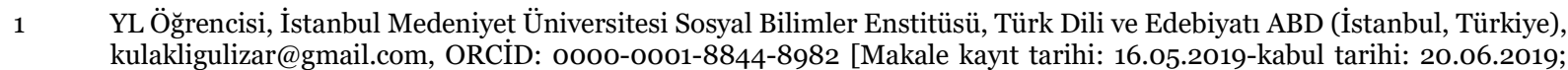
kulakligulizar@gmail.com, ORCID:
DOI: 10.29000/rumelide.580750] 
çözmeye çalıştığını belirtmiştir. Bu bölümde son olarak çalışmanın üç yöntemden meydana geldiği belirtilmiştir ki bunlar: Metaforik eşleştirme, kuramsal eleştiri ve soykütüğ̈̈dür (ya da eleştirel tarih).

"Palimpestlerin Bir Tarihçesi” başlığını taşıyan ikinci bölümde, palimpsest tekniğinin kullanılışından ve palimpsestlerin tarihi süreç içerisindeki öneminden bahsedilmektedir. Bu bölüm, 'Arşimet Palimpsesti', 'Yaratılış: Antikçağdan Ortaçağa', 'Diriliş: 18. Yüzyıldan 21. Yüzylla' olmak üzere üç alt başlı̆̆a sahiptir. Milattan önceki yüzyıllardan başlayarak 21. yüzyıla kadar varlığını sürdürmüş olan bu tekniğin en meşhur ve en önemli örneği olarak Arşimet Palimpsesti gösterilir. Katmanlaştırma, silme ve üstüne yazma süreciyle meydana gelen palimpsestler sonraki kuşakları da etkilemiş ürünlerdir. Bunun nedeni ise, tirşedeki ilk yazının silinmiş gibi görünse de çoğu zaman silinmeyip izler bırakmış olmasıdır. Arşimet Palimpesti uzun yıllar muhafaza edilmiştir. Yazar, Arşimet Palimpestinin bir dua kitabının içerisinde yer almasından dolayı muhafaza edildiğini düşünmektedir.

Palimpsestleştirme tekniği 15. yüzyılın sonunda kâğıt miktarındaki artış ve matbaanın icadıyla verimsiz bir hâle gelmiş olsa da yeni keşiflerle beraber zirve dönemini 19. yüzyılda yaşamıştır. Dillon, 19. yüzyılın en ünlü palimpsest editörü olarak İtalyan âlim Kardinal Angelo Mai'yi gösterir. 21. yüzyılın başlarında gelişen görüntüleme teknolojisinden yararlanmanın yanı sıra kimyevî madde kullanımlarından, kızılötesi ve ultraviyole ışıklarından da yararlanarak palimpsestlerin zirve dönemini yaşadıkları tespit edilir. Bu bölümde palimpsestlerin sadece paleografik alanda kullanılan nesneler olmadığı belirtilir. Tarihsel açıdan önemli oluşunun altı çizilerek hayal gücümüzü zenginleştirdiği de vurgulanır.

“Zihnin Palimpsesti” başlığını taşıyan üçüncü bölümde ise metafordan yararlanılarak zihin ile palimpsestlerde kullanılan parşömen parçaları arasında bir benzeşim yapılır. Bu bölüm, 'De Quincey'nin Diriliş Fantezileri', 'Hayaletsellik: Öznellik ve Zamansallık', 'Buluşcu Okuma', 'Palimpsestvari Tropografiler' olmak üzere dört alt başlı̆̆a sahiptir. Bu bölümün hareket noktasını insan beyni, zihni oluşturur. Dillon, palimpsestlerin katmanlarının nasıl ki birtakım tekniklerle ortaya çıkarılacağını düşünüyorsa aynı şekilde zihnin palimpsestlerinin de aydınlatılabileceğini düşünür. Dillon, burada söylediklerini somutlaştırmak amacıyla De Quincey örneğini verir.

Kız kardeşi Elizabeth’i ve annesini kaybeden De Quincey, bu ölümlerden çok etkilendiğini ve bu kayıpların palimpsestten silinmeyecek kadar trajik olduğunu söyler. Dillon, bu bölümde De Quincey’in yaşamı ve eserleri arasındaki ilişkiyi inceler. De Quincey palimpsestlere hayrandır. Çünkü; onların koruyucu işlevinin olması ve diriliş olanağı sağlaması hayranlık verici bir özelliktir. Bu diriliş fikri sayesinde De Quincey kız kardeşinin ölmediğine, onun sadece bir uykuda olduğuna inanır. Dillon, ayrıca bu bölümde Nicolas Abraham ve Maria Torak'ın kripta kavramı ile palimpsest kavramını birleştirir. Palimpsestin kriptayla birleştirilmesi sonucunda palimpsest kavramının girift (karmaşık) yapısına, varlığına dikkat çeker.

"Şiir Sanatı ve Metafor Üzerine" başlığını taşıyan dördüncü bölümde ise Amerikalı şair D.H. Lawrence'nin "Alacakaranlı̆̆ın Palimpsesti” adlı şiirinden hareketle bir inceleme yapılmıştır. Bu bölüm, 'Birlikte Ait Olma: Heidegger ve Metafor', 'Metaforun Metaforları', 'Şimdinin Şiir Sanatı: D.H. Lawrence' olmak üzere üç alt başlıktan oluşmaktadır. "Alacakaranlığın Palimpsesti” adlı şiir ilk önce "Hafta İçinde Bir Günün Akşamı” adıyla düşünülmüş daha sonra gözden geçirilip Secker’in New Poems baskısında son başlığıyla şeklini almıştır. New Poems'te yer alan şiirlerini gözden geçiren Lawrence bu sefer The Collected Poems'te başka bir düzenlemeyle şiirin başlı̆̆ını değiştirip 'Alacakaranlık' başlığı ile yayımlamıştır. Metin üzerinde bir değişiklik olmadığı halde taslak metin üzerinde yapılan silmeler, yazmalar, yeniden yazmalar palimpsest kavramını çağrıştırır. Bu bölümde düşüncelerine yer verdiği 
Michael Davidson ise Dillon'a farklı bakış açıları kazanma olanağı sağlamış bir kişidir. Bir metnin diğer bir metnin kaynağı olamayacağını düşünen Davidson, 'palimptekst' kelimesini uydurduğunu söyler. Bu uydurma kelime ile berber gelenekselleşen birtakım olgular da değişmeye başlamıştır. Altta yatan metni kurtarmaya çalışan ve bunu yaparken de gelenekselleşen palimpsest okuma kalıpları yıkılarak yerini katmanlar arasındaki ilişkilerin çözülmesine bırakır. Palimpsestvari ya da palimtekstüel diye adlandırılan bu okumada tüm katmanlar dikkate alınarak hiyerarşi gözetilmez. Dillon, bu bölümde Martin Heidegger’in düşüncelerine yer vererek palimpsest ile metafor kavramlarının benzerliğinden bahseder. Teorisini güçlendirmek amacıyla da Derrida’nın yapmış olduğu bir çalışmadan örnek verir.

"Riskli Okuma" başlığını taşıyan beşinci bölümde ise geleneksel dedektif hikâyelerinin kurgusu ile palimpsest arasında bir ilişki kurulmuştur. Bu bölüm 'Eleştirel Metin (1): Klasik Dedektif Romanı Üzerine', 'Kuramsal Metin (1): Yapısalcıllk Üzerine', 'Eleştirel Metin (2): Modern Dedektif Romanı Üzerine', 'Kuramsal Metin (2): Postyapısalcılık Üzerine' olmak üzere dört alt başlı̆̆a sahiptir. Dillon bu bölümde Arthur Conan Doyle'in Sherlock Holmes adlı eserinden yaptı̆̆ı bir alıntı ile başlar. 'Altın Gözlüğün Esrarı' adlı hikâyeden yapılan alıntıdan sonra Dillon, bu hikâyenin bir eleştirel spekülasyona yol açtığını belirtir. Albert Silverstein bir yazısında Holmes hikâyelerinin anlatıcısı olan Dr. Watson'un anlattığı hikâyelerin sağlam bir kurgusunun olmadığını belirtir ve onları klasik dedektif romanlara benzetir. Dillon'a göre ise bu metin, palimpsest okuması ile dedektif okuması arasında bir metaforik bağlantı kurar. Çünkü dedektif anlatılarının olay örgüsü ile palimpsestlerin yapısı arasında bir benzerlik bulunur.

Klasik dedektif romanlarının iki ana unsura sahip olduğuna işaret edilerek, bunlardan ilki suçu işleyenin sildiği veya silmeye çalıştı̆̆ı olayların 'gerçek' versiyonu, ikincisi ise, olayların görünüşteki versiyonunun hikâyesidir. Dillon dedektif hikâyelerinin okuru ile palimpsest editörlerini birbirine benzetir. İkisi de bir tür dedektiflik okuması içindedir. Her ikisinin yapılabilmesi için de yetenekli bir okur olunması gerektiği belirtilir.

Palimpsest dedektif okuması bir keşif sürecini içerir. Okur bu süreç içerisinde tümdengelim'e değil, abdüksiyon'a (varsayımsal çıkarım/ retrodüksiyon) dayanır. Dillon, yapısalcıllk üzerine önemli çalışmalarda bulunan Ferdinand de Saussure'nin de abdüksiyon yöntemini kullanarak bir okuma yaptı̆̆ını söyler. Dillon burada edebiyat eleştirmeni olan iki isimden de faydalanır: Jean Starobinski ve Michael Riffaterre.

Dillon daha sonra Umberto Eco'nun Gülün $A d \imath$ adlı romanı üzerinde durarak örneklerle palimpsest metaforunu açıklar. Gülün $A d \imath$ romanındaki William'ın dedektif okuması ile dedektif palimpsest okumasının aynı metodolojiye sahip olduğunu düşünür. Gülün Adı klasik dedektif kurmacasının bir palimpsestidir; yüzeyinde hem eski hem de yeni türde dedektif okumasının palimpsestvari mahremiyetinin dünyası vardır. Bu nedenle Gülün Adı klasik değil, modern bir dedektif romanı tanımına girer. (s. 109).

Dillon bu bölümde son olarak Roland Barthes’in “Metin Kuramı” yazısını ele alır ve Barthes’in 'Metinsel analiz’ adını verdiği yeni bir okuma türünden bahseder.

"Metinlerarasıllğı Yeniden Düşünmek" başlığını taşıyan altıncı bölümün hareket noktasını Sigmund Freud, Roland Barthes, Jacques Lacan, Jacques Derrida, Mihail Bahtin gibi kişilerden etkilenen edebiyat teorisyeni ve psikanalist olan Julia Kristeva oluşturur. Kristeva, postyapısalcı kuramda da çok sık kullanılan 'metinlerarasılık' kelimesini dile kazandıran kişidir. O, metni bir metinlerarasıllk, bir 
permütasyon ve bir mozaik olarak görür, bu kavramlara göre tarif eder. Dillon bu bölümde iki metinden yola çıkarak metinlerarasılık kavramını palimpsestvari okuma yaparak incelemektedir. Bu iki metin şunlardır: Gérard Genette'in Palimpsestes ve Ian McEwan'in Kefaret'i.

'Genette'in Palimpsesti' alt başlığını taşıyan bölümde Palimpsestes adlı kitabın öneminden bahsedilir. Bu kitap, palimpsest kavramını alana taşıması bakımından temel bir metin görülmekle beraber, metinlerarasılık çalışmaları alanında da kilit bir metin olarak kabul edilir. Genette, metnin metinsel aşkınlığı olarak tanımladığı metinlerötesilik kavramını ise dört grupta tasnif eder: Metinlerarasılık, yanmetinsellik, üstmetinsellik ve hipermetinsellik. Dillon vermiş olduğu örneklerle bu kavramları somutlaştırır.

‘Kefaret (1999/2001) alt başlığını taşıyan bölümde ise Ian McEwan'ın Kefaret adlı kitabı esas alınır. Bu kitap Jane Austen, Virginia Woolf, Elizabeth Bowen, Rosamond Lehmana gibi yazarların eserlerine yapılan atıflardan oluşur. Dillon, metin üzerinden vermiş olduğu örneklerle romanı metinlerarasılık bağlamında değerlendirir. Burada özellikle zamansallık kavramı ön plana alınarak bir inceleme yapılır.

"Palimpsestin Queer'leştirilmesi: H.D." başlı̆̆ını taşıyan yedinci bölümde yazar, toplumsal cinsiyet ve feminizm gibi konulardan hareket eder. Feminist eleştirinin görevinin metinlerin içinde bastırılmış anlatıları keşfedip gün ışığına çıkarmak olduğunu düşünen Dillon, bu tür okumada da eksik yönlerin olduğunu tespit eder. Dillon, bu bölümde Amerikalı şair ve romancı olan H.D.'nin Palimpsest eserini oluşturan metinlerden ikisini seçerek onlar üzerinde durur: 'Murex: War and Postwar London' ve 'Secret Name: Excavator's Egypt'. Bu metinlerin dokusunda toplumsal cinsiyet, cinsel kimlik ve heteroseksüellik ile eşcinselliğin olduğunu vurgulayan Dillon Palimpsestvari okuma yaparak bir değerlendirmede bulunur. Kitabın son bölümünü oluşturan başlıklardan biri "Notlar"dır. Bu bölümde yazarın kitap içerisinde vermiş olduğu bazı bilgilerin açılamalarına ulaşılabilir.

Sonuç olarak, Palimpsest edebi eleştiri, kuram, postmodernizm, postyapısalcıllk, feminizm gibi konularda araştırma yapacaklar için bilgi, yöntem ve kaynak yönünden zengin bir eserdir. Kitabın giriş bölümünün 'Palimpsest' kavramını açıklayıcı nitelikte olması ise, konu hakkında bir bilgisi olmayan ve bu kavramla ilk kez karşılaşan insanlar için hem merak uyandırıcı hem de öğretici bir niteliktedir. Yedi bölümden oluşan bu kitabın her bir bölümünde farklı kitaplardan ve alıntılardan verilen örneklerle kavramlar daha somut hale getirilmiştir. Bu da somutlaştırılıp anlamlandırılması kolay olmayan bazı kavramların okuyucunun zihninde daha kolay somut hale getirilip anlaşılmasını sağlamıştır. Palimpsest: Edebiyat, Eleştiri, Kuram adını taşıyan bu eser, disiplinlerarası alanda çokça faydalanılan palimpsest kavramını her yönüyle açıklığa kavuşturmasının yanı sıra kullanılan kaynaklar açısından da zengin bir içeriğe sahiptir. Bu yönleriyle eser, sadece edebiyat alanında değil, farklı disiplinlerde çalışmalar için de oldukça yeni bakış açıları sunmaktadır. 